\title{
1 Gendered poverty across space and time: introduction and overview ${ }^{1}$ \\ Sylvia Chant
}

The past 15 years have borne witness not only to the prioritisation of gender inequality and poverty as two of the most challenging barriers to social and economic justice in a globalising world, but also to their progressive intertwining. This is as much the case in policy as in academic arenas, and owes in no small measure to the significance formally attached to addressing women's poverty by the Beijing Platform for Action (BPFA) launched in 1995 at the Fourth World Conference on Women (FWCW). Although for innumerable countries the historical record (albeit anecdotal rather than empirically or statistically rigorous) had suggested that women's economic disadvantage was not new, impetus for the Beijing breakthrough was spawned by a novel globalised assertion: that women were as many as 70 per cent of the world's poor. This categorical and seemingly bona fide statement (at least as intimated by its rapid adoption and circulation in the policy and academic literature) was usually accompanied by the ominous sub-clause that the level was likely to rise (see Chant, 2008; Moghadam, 1997). ${ }^{2}$

The BPFA's ensuing exhortation to eliminate gender bias in poverty worldwide became something of a cause célèbre given prior tendencies for poverty analyses to deal in the currency of 'sexless averages' (Johnsson-Latham, 2004: 18), and for gender's common neglect in anti-poverty programmes (UNDP, 2000: 3). Thanks in large measure to Beijing, the period from the mid-1990s onwards has seen an unprecedented number of countries introducing new programmes (or strengthening existing ones) to combat poverty among women. Such interventions both reinforce and are reinforced by the mission statements of institutions representing different world regions. For example, the Asian Development Bank rationalises its call for gendered poverty interventions on grounds that the 'overarching goal of poverty reduction is closely linked to improving the status of women, since equity - especially gender equity - is now recognised as an essential factor in transforming growth to development, and reducing poverty' (ADB, 2002: 135). In turn, the Economic Commission for Latin America and the Caribbean stresses one of its main priorities as identifying 'the characteristics of female poverty and its associated causes' (ECLAC, 2004: 82). At a wider international level, some of the world's poorest countries which have sought debt relief under the HIPC (Heavily Indebted Poor Countries) initiative have been bound in principle, if not necessarily in practice, to 'mainstream gender' in their Poverty Reduction Strategy Papers (PRSPs) (see Bradshaw and Linneker, 2003; Whitehead and Lockwood, 1999). Microfinance schemes in developing nations are also disproportionately directed to women (see Goetz and Sen Gupta, 1996; Mayoux, 2006), as are conditional cash transfer (CCT) programmes, although directing resources through women might be a more apposite description for the latter (see Bradshaw, 2008; Molyneux, 2006; also González de la Rocha, 2006a, and below). At a global level, all United Nations (UN) member states are urged both 


\section{The international handbook of gender and poverty}

to reduce extreme poverty and to promote gender equality and the empowerment of women, as part and parcel of eight 'universal' goals for the early twenty-first century established by the Millennium Declaration (see Chant, 2007a: ch. 1; Sweetman, 2005). Just a few months before the present Handbook was completed, and in response to the global financial crisis which broke in 2008, the Women's Working Group on Financing for Development called upon the UN to (re)position itself as leader in a 'new global development, economic and financial architecture' with the full integration of gender equality and women's rights. ${ }^{3}$ And the theme of the five-yearly World Survey on the Role of Women in Development of 2009 is 'Women's control over economic resources and access to financial resources, including microfinance' (UN-DESA/UNDAW, 2009). On the surface, at least, the general context for institutional and policy directives to reduce poverty gaps between women and men has never looked so propitious.

Yet the task of converting the goal of reducing gendered poverty into actual results is far from straightforward. Quite apart from the uneasy tensions between market growth and poverty reduction, and the towering barriers to gender justice and rights posed by the new neoliberal world order (see for example, Cornwall et al., 2008a; Cornwall and Molyneux, 2007; Molyneux and Razavi, 2002; Perrons, 2004; Razavi, 2009; Sweetman, 2005), as has become well rehearsed in the feminist literature, gender is not just about women, and poverty is not just about income (see Chant, 1997, 2007a; Fukuda-Parr, 1999; Jackson, 1996). The complex intersections between these two heterogeneous entities accordingly require analysis, assessment and interventions which are fine-tuned to a multiplicity of conceptual, contextual and practical specificities. As Sarah Bradshaw, a contributor to this volume (Chapters 79 and 96), so concisely describes in relation to her work on Nicaragua, women's poverty is 'not only multidimensional but is also 'multisectoral ... [and] . . . is experienced in different ways, at different times and in different "spaces" (Bradshaw, 2002a: 12). These spaces include, inter alia, the home, the community, the labour market, the realm of assets and property ownership, the legal environment, the social policy arena, the political economy, and territories of war, conflict and natural disaster (see for example, Afshar, 2003; Bradshaw, 2002a, 2002b; Chant, 2007b; Clark and Moser, 2001; CLEP, 2008; Deere and Doss, 2006; Enarson and Chakrabarti, 2009; Enarson and Morrow, 1998; Folbre, 1994, 2006; Hart, 1995; Mazurana et al., 2005; Moser, 2007; Parpart and Zalewski, 2008; Razavi and Hassim, 2006; Rodenberg, 2004). Beyond this, gendered poverty is also experienced by men and boys, and is differentially impacted by a whole series of factors such as age, 'race', nationality, sexuality, class, household headship and composition, the marital, fertility and family status of women and men, urban versus rural provenance and residence, migration within and across national borders, availability of public as well as private assets, labour market possibilities in the formal and informal economy, and state social transfers (see Barker et al., 2007; Chant, 2007a; Cornwall et al., 2007, 2008b; Fernández-Kelly and Sassen, 1995; Piper and Roces, 2002; Razavi, 2009; Ruxton, 2009; Tronto, 2002; Vera-Sanso, 2006). Many of these variables not only intersect with gender and poverty, but with one another, and exert diverse influences and outcomes depending on whether one's 'take' on poverty is filtered through the conceptual lens of monetary poverty, capability poverty, social exclusion, and so on; whether it is oriented more to 'objective'/quantitative or 'subjective'/qualitative/participatory measures; ${ }^{4}$ and/or is personal, domestic, local, national or global in its subject or spatial orientation. The nuancing of different terminologies to 
describe the relationships between gender and poverty is also critically important. For example, while the expressions 'gender gaps in poverty', 'gender-specific poverty' or even 'gender-differentiated poverty' commonly imply a particular kind of poverty (largely materially based, and usually focused on income, consumption or financial assets), the term 'gendered poverty' (or perhaps 'gendered poverty burdens'), summons up a broader notion whereby poverty - and gender - are less predetermined and static. The concept of 'gendered poverty' opens up scope for a range of perspectives on the diverse meanings, causes, processes and outcomes embroiled in different forms of privation among women and men, and on their intersections with a host of social, economic, demographic and other cleavages. Although issues of gender gaps in earnings, expenditure and the like remain vitally important elements under this more flexible and dynamic umbrella term, and there is strong evidence for persistent and ubiquitous gender differences in access to economic resources, major doubts have been mooted in the feminist literature about whether income should be pre-eminent in gender-sensitive conceptions of well-being, and whether tackling income poverty is the most effective strategy for solving women's disadvantage. As Johnsson-Latham (2004: 26-7), among others, has contended, income is probably a less 'robust' indicator of women's privation than factors such as access to land, agency in decision-making, legal rights within the family, vulnerability to violence, and (self-)respect and dignity. The primacy routinely accorded to income in poverty assessments may also minimise other practical and potentially measurable, as well as subjectively interpreted and experienced, dimensions of poverty such as 'overwork', 'time deficiency', 'dependency' and 'powerlessness'. As a growing body of research in different geographical contexts has revealed, the latter may be as, if not more, relevant to women's perceptions of disadvantage, and to the 'trade-offs' they are able to make between different aspects of poverty (Blanc-Szanton, 1990; Chant, 1997; Fonseca, 1991; Fukuda-Parr, 1999; Kabeer, 1997; Sen, 1999; Whitehead and Lockwood, 1999). It is something of the multifarious character, causes and consequences of gendered poverty, and how these elements and their interactions might be conceptualised, investigated and measured, which constitutes a primary aim of the present volume.

Also of major importance in this Handbook is how policy interventions may address the complexities of gendered poverty in a positive and effective manner. While nation states, non-governmental organisations (NGOs), and bilateral and multilateral agencies are often genuinely well-intentioned in their bids to reduce poverty and promote gender equality - increasingly under the banner of 'empowering women' - a number of pitfalls and unintended consequences are glaringly evident. One is the tendency for a rich body of feminist analysis on gendered poverty to get 'lost in translation' at various stages of policy design and implementation (see Longwe, 1995). Even the coining of guiding rhetoric itself, such as one of the most popularised shorthands, the 'feminisation of poverty', 5 has proved deeply problematic. On one hand this has been quite effective at garnering resources for women (Chant, 2008), and nominally, at least, has served as a 'marching call that impels us to question our assumptions about poverty itself by examining how it is caused, manifested and reduced, and to do this from a gender perspective' (Williams and Lee-Smith, 2000: 1; see also Wennerholm, 2002). Yet, on another hand, the term 'feminisation of poverty' is actually semantically incorrect in respect of its usual referent, namely, a state rather than a process (Chant, 2008; Medeiros and Costa, 2006). Furthermore, the 'feminisation of poverty' construction could be charged with having 


\section{The international handbook of gender and poverty}

simplified concepts of both poverty and gender such that some individuals in need are missed, those individuals most associated with the phenomenon (particularly female heads of household) are scapegoated as part and parcel of the 'problem', and issues of major importance in feminised poverty, such as gendered power relations within as well as beyond the household, are glossed over (Chant, 2008; Davids and van Driel, 2001, 2005; Lampietti and Stalker, 2000; Medeiros and Costa, 2008; Molyneux, 2006; Moore, 1994; Quisumbing and McClafferty, 2006; Sen, 2008; Varley, 1996). While a dedicated section of the Handbook deals with these issues, it is pertinent here to recall Robert Johnson's (2005) argument that poverty interventions have tended to be rather more preoccupied with addressing the condition of poor women (primarily their material circumstances), than their position (their place and power within domestic units and in wider society). In turn, steps to improve women's poorer condition have rarely challenged men's condition or position (Johnson, 2005: 57, emphasis in original). Notwithstanding the importance of income in helping women to challenge other aspects of inequality, therefore, boosting women's economic status is unlikely to go very far on its own given that the "feminisation of poverty" is . . . an issue of inequality that extends to the very basis of women's position in economic relations, in access to power and decision-making, and in the domestic sphere. It is emphatically not addressed in a sustainable manner solely by measures to improve the material conditions of women' (ibid.; see also Jackson, 1996; Kabeer, 2003; Sweetman, 2005: 6; UN/UNIFEM, 2003).

Leading on from this, another prevailing concern in the realm of planned interventions is the instrumentalist manner in which anti-poverty initiatives such as microcredit and CCT programmes rely heavily on women as a 'conduit of policy' (Molyneux, 2006, 2007). Through capitalising on women's economic prudence and/or 'voluntary' unpaid labour in the context of assumptions about women's 'traditional' roles as altruistic wives and mothers, such initiatives may simply add to already heavily feminised burdens of poverty-associated labour, time and expenditure (see Bradshaw, 2008; Brickell and Chant, 2010; Chant, 2008; Molyneux, 2007; Roy, 2002; UN/UNIFEM, 2003). As summarised by Stefan de Vylder (2004: 85), the pursuit of gender equality has normally been regarded by the GAD community as an end in itself and from a human rights perspective; yet from the vantage point of stakeholders whose primary interest is in alleviating poverty in general, the incorporation of women into poverty reduction programmes may be driven less by imperatives of social justice than by goals of pragmatism and efficiency (see also Mayoux, 2006). ${ }^{6}$

Accepting the contention that poverty and gender inequality alike are 'morally unacceptable' (Medeiros and Costa, 2008: 115), it is vital that both feature as policy priorities in the twenty-first century. Further, if addressing gendered poverty is to be uppermost, it is crucial that more informed and imaginative ways are devised to ensure the attainment of comprehensive, and sustainable, gender justice 'on the ground'. Again, this volume aims to identify some critical ways forward, both in the context of initiatives on the part of institutional stakeholders, as well as those generated by women and men at the grassroots.

\section{Organisation of the Handbook}

The remainder of this chapter sketches out the organisation of the Handbook, which, given its extensive thematic and geographical range, requires some basic navigational guidelines. These guidelines mainly consist of a rationalisation of my choice of 
subsections, and brief pointers to the topics and highlights in each. I refrain from discussing more than the sparest details of content and argument of individual chapters, just as I adopted a generally light touch to how my authors approached their contributions in the first place. Such a format not only permits a diverse international and multidisciplinary body of experts to speak directly to readers, but minimises what I feel may be a gratuitous second sight, with even more elaborate vignettes still unlikely to do justice to the fine-grained complexities of a huge number of specialist subject areas.

Bearing in mind that the cross-cutting nature of issues, ideas and arguments made dividing the fruits of my editorial endeavour extremely difficult, I settled on ten broad sections, hereafter referred to as 'parts', which as far as possible dovetail with the particular content and context of contributors' chapters, but which should not be read as analytically discrete. Indeed, themes such as the intersectionality of gender with other criteria of social difference, the undervaluation of women's paid and unpaid labour, gendered asset inequalities, power, agency, discrimination, and so on, stretch right across the volume. To signpost some of the more critical links, cross-references are made to other chapters and parts throughout. It should also be noted that the ordering of the sections (and the chapters therein) does not indicate any particular priority in respect of their conceptual, methodological or policy significance, with many of the more area-specific case studies speaking to theoretical debates well beyond place or subject boundaries.

With the above in mind, I chose to begin the volume with a part entitled 'Concepts and Methodologies for Gendered Poverty', in which a set of chapters considers in broad terms how different aspects of gendered poverty might be approached, analysed and measured. Saskia Sassen's opening discussion (Chapter 2), for instance, which has particular resonance for aspects of migration and work dealt with later in the Handbook, introduces the importance of 'strategic gendering' to a range of international economic processes past and present, and particularly the 'alternative political economies' associated with the current phase of globalisation. This links with another of Sassen's concepts, the 'feminisation of survival', by which she refers to the increasing significance of women's labour not only in underpinning household livelihoods - across the social spectrum and frequently across borders - but also in sustaining states and global corporations. The inclusion of women's subjective experiences of poverty and exploitation - for example, as migrant or minoritised workers forming part of the 'serving classes' responsible for the 'smooth functioning' of professional households - is one way to unseat a persistent gender-neutrality in analyses of economic globalisation which so often selectively invisibilise labour regimes which are key to its existence and evolution.

The question of subjectivities is taken further by Henrietta Moore (Chapter 3) who stresses how gendered poverty analysis may be enriched not only by taking into account subjective interpretations of poverty and well-being, but by adopting a much more explicit and theoretically informed analysis of gendered subjectivities in ways which depart from naturalised and universalised assumptions about the sites in which these are predominantly configured, such as heterosexual marriage and 'conventional' households. A particular preoccupation in Moore's discussion is that of how social and economic inequalities engage with women's and men's views of morality and selfhood, and how such an approach opens up a more historically and culturally sensitive space in which to analyse the intersections of gender and poverty.

In Gerd Johnsson-Latham's chapter (Chapter 4), attention turns to how power, 
privilege and gender are reflected in poverty analysis and development goals. Identifying two main schools of thought on the interrelations between gender and poverty - the 'poverty discourse' and the 'gender discourse' - Johnsson-Latham shows how the knowledge and policy prescriptions of the latter (predominantly concerned with gender justice, rights-based approaches, and poverty broadly defined) are often overshadowed by the former (more concerned with economic growth, and monetary poverty) not least in the formulation of the MDGs. To strengthen the knowledge base from which gendered poverty analysis and action take their lead, much more primacy to a Gender and Development (GAD) approach is necessary.

Echoes of these (as well as Moore's) arguments are found in Cecile Jackson's chapter (Chapter 5), which, with particular reference to India, stresses how gender inequality cannot be collapsed to poverty and vice versa. Observing that economic growth rather than poverty is often responsible for increasing gender inequalities, Jackson's discussion foregrounds the need for gender-focused policy which extends beyond targeted interventions to low-income women.

The next cluster of chapters in this part deal with the measurement of gender inequality, in which various types of poverty are implicated. The chapters by Thomas Pogge (Chapter 6) and Sharon Bessell (Chapter 7), for example, reflect on the limitations of existing indicators, such as international poverty lines and the poverty and gender indices developed by the United Nations Development Programme (UNDP), to capture experiences of gendered poverty. Among the suggestions made to improve measures are a more comprehensive range of variables, and the factoring in of information generated through participatory assessments. Examples of some of the more specific issues vital to enhancing the gender-sensitivity of poverty indicators are rights and equality (as discussed in the chapter by Anna Coates, Chapter 8) and time poverty (Sarah Gammage, Chapter 9).

A new measure - the Social Institutions and Gender Index (SIGI) developed at the Organisation for Economic Co-operation and Development (OECD) - is introduced in the chapter by Dennis Drechsler and Johannes Jütting (Chapter 10). Notwithstanding persistent and uneven data gaps, the SIGI attempts to incorporate a far wider range of variables pertinent to gender inequality and poverty than most of its predecessors, including the provisions of national Family Codes, son preference and gender disparities in ownership rights.

The last chapter in this section, by Linda Mayoux (Chapter 11), discusses the 'Gender Action Learning System' (GALS), which aims to elicit the key factors in household poverty. In its application in a range of countries in the Global South, GALS has revealed the centrality of gender inequalities, such as in relation to violence and property rights, to individual privation. As a proven gender-sensitive participatory tool in specific localities, this could be an important addition to more qualitative methodologies for poverty assessment in general.

The second part of the Handbook is entitled 'Debates on the "Feminisation of Poverty", and Female-headed Households'. Although it is increasingly recognised that the 'feminisation of poverty' is a lumpen term of little theoretical, explanatory or even descriptive utility, and one whose association with female-headed households is tenuous, despite its origins in relation to Afro-American women and their households in the United States (US) (Pearce, 1978), chapters dealing with one or both these phenomena are grouped here for two interrelated reasons. The first is on account of the historical 
positioning of discussions of female household headship within expositions (or critiques) of the 'feminisation of poverty'. The second is because the majority of authors in this section make reference to both issues. With this in mind, Part II opens with a discussion by Marcelo Medeiros and Joana Costa (Chapter 12) on the extent to which available statistics corroborate a trend towards a 'feminisation of poverty'. Beyond the conclusion that the evidence for such an assertion is weak, one of the main points in Medeiros's and Costa's discussion revolves around the methodological significance of whether the unit of analysis is the individual or the household. This is also taken up by Gita Sen (Chapter 13), who further echoes some of the issues discussed by Jackson about pockets of gendered poverty (including violence, and 'time tax') within well-off as well as poor (not to mention, male-headed) households.

One of the major downsides of persistent assumptions about the 'feminisation of poverty', and again perhaps most notably its association with female household headship, is the reproduction of heteronormative orthodoxies such as the 'male breadwinner' paradigm. This comes in for close discussion by Tine Davids and Francien van Driel (Chapter 14), who propose the adoption of a multilayered 'gender lens' which minimises essentialist assumptions about women's and men's behaviour, power and agency in a world in which processes of globalisation are often deeply associated with what they denominate as 'false dichotomies'.

Another slant on the 'feminisation of poverty' is presented in my own case study chapter (Chapter 15), which, on the basis of fieldwork in The Gambia, Philippines and Costa Rica, distils a tendency over time towards a 'feminisation of responsibility and/ or obligation'. This leads me to advocate that the analytical parameters of the 'feminisation of poverty' are broadened beyond income to include gender-differentiated inputs of labour and time into household livelihoods, as well as taking into account male - as well as female - household headship. These suggestions seem to have resonance in other contexts, with Lynne Brydon (Chapter 16) noting a similar trend towards a 'feminisation of family responsibility' over nearly forty years of longitudinal anthropological observation in Ghana.

The chapters based on comparative work by Helen Safa (Chapter 17) in Cuba, Puerto Rico and the Dominican Republic, and by Janet Momsen (Chapter 18) in various Caribbean islands, transport us to another area of the Global South where femaleheaded households have a long and comparatively well-documented history. Safa's particular concern is the way in which state policies under socialist and non-socialist regimes have impacted on the formation and viability of female-headed units, whereas Momsen concentrates on factors such as violence and HIV/AIDS which appear to be undermining the relative success traditionally achieved by female-headed households in survival and well-being. Another potential threat for female-headed households comes from war and civil conflict, as explored by Marian Koster (Chapter 19) in the aftermath of the Rwandan genocide of the early 1990s. Like Caroline Moser, whose discussion of asset accumulation in Ecuador is featured later in the volume, Koster finds that femaleheaded households may not necessarily be income-poor (as is often imagined to be the norm), but face asset vulnerability on account of limited access to land.

The succeeding chapter, by Annelou Ypeij (Chapter 20), traces the experiences of migrant lone mothers of Dutch Caribbean origin as well as those of indigenous nationals in Amsterdam. One of the main patterns highlighted by Ypeij is an intensification of social 
stigmatisation against lone mothers in receipt of welfare benefits as the Netherlands, like many countries, pares down social expenditure. That state support for lone mothers and women in general - should not be compromised is further urged in Jane Millar's discussion (Chapter 21) of lone mothers in the UK which identifies, inter alia, the critical role played by subsidised childcare in reducing poverty. The UK - along with other European countries, the USA and Canada - also forms a focus in Fran Tonkiss's chapter (Chapter 22) on the advanced economies. Following her discussion of the intersectionality of gender with household headship and composition, 'race', age and space, Tonkiss draws the conclusion that for diverse social groups disadvantage persists in being 'feminised', even if the determination of precise trends remains difficult.

In Part III on 'Gender, Family and Lifecourse' we move into the more general terrain of households and families, taking into consideration different lifecourse phases - ranging from youth to old age - as well as inter- and intra-generational relations. In the first chapter here, Agnes Quisumbing (Chapter 23) sets out a review of gender and household decision-making, paying particular attention to the utility of different theoretical models, and how vital elements such as 'bargaining power', which she sums up as 'a most elusive concept', can be measured and accounted for. Making reference to case studies from different developing countries, Quisumbing emphasises the important influences of social norms and control over resources in intrahousehold allocation, including, again, access to assets.

In respect of intergenerational household dynamics and their relations with poverty, Ruth Lister's discussion of the UK (Chapter 24) pays particular attention to the manifold ways in which women's poverty undermines their perceived and actual capacity to live up to parenting norms, and how raising children, in turn, obstructs their ability to exit poverty. Among the main issues driven home in Lister's chapter is how the responsibility for managing poverty, which usually falls to women, entails hard, complex, timeconsuming and exhausting labour burdens, often little alleviated by state support.

A somewhat more specific perspective on the links between women's and children's poverty is provided by John Sender (Chapter 25) on the basis of Mozambique, where he considers the impacts of female wage labour on investments in children's education. As often found in other poor countries, where education is a costly undertaking for parents, girls tend to do better in respect of schooling where their mothers have income in their own right, even where they have to manage without the wage of a male partner.

Households and intra-generational divisions and dynamics - particularly between spouses - are a major interest in Sarah Ashwin's chapter (Chapter 26) on gendered experiences and outcomes of poverty in post-Soviet Russia. Here she concentrates on employment and domestic labour through the years of transition from a centrally planned to a market economy, highlighting continuities in women's attachment to the labour force (mainly as a result of economic need), and men's peripherality to unpaid reproductive labour. The latter obtains even as threats to men's breadwinning position have intensified, which also appear to have provoked a rise in risk-taking behaviour, especially alcoholism. In light of the traumas attached to male marginalisation, and notwithstanding the knockon effects on women's income- and time-poverty, women's continued responsibility for domestic labour and childcare arguably comprises a rather more positive than usual connotation insofar as it helps them to sustain a sense of 'efficacy, competence and meaning'.

Other post-Soviet states in Central Asia, such as Tajikistan, as discussed by Jane 
Falkingham and Angela Baschieri (Chapter 27), reveal similar patterns in women's continued straddling of paid and unpaid work, despite the substantial withdrawal of state support for childcare and parental leave, and a renaissance of Tajik cultural values of male authority. One issue of particular relevance to gendered poverty raised by these authors is the need for assessments of household income which do not assume equality of pooling and allocation.

A somewhat different perspective on household experiences of poverty is presented by Carolyn Williams (Chapter 28) in her discussion of Peru. This chapter draws out some of the links between sexuality, gender and poverty explored in other parts of the volume with particular reference to a close study of family life in Lima's low-income settlements. Here Williams highlights the various forms of discrimination and isolation faced by women on account of their experiences of same-sex desire and relationships, and the strategies they deploy for overcoming the negative effects of not conforming with heterosexual norms.

Also dealing in various degrees with sexuality are the next three chapters in Part III which consider issues around youth. Gareth Jones and Sarah Thomas de Benítez (Chapter 29) explore gender differences in work and life among Mexican streetchildren, finding, among other things, that in spite of their non-normative economic, social and cultural positions male and female street youth often subscribe to dominant gendered ideals of work and caring as part of their survival strategies.

Survival strategies are also key to Alice Evans's (Chapter 30) discussion of sexuality and poverty among young people in The Gambia, where sexual partners are commonly regarded as providers of economic resources, as highlighted for other sub-Saharan African (SSA) countries discussed elsewhere in the Handbook by Moore, Campbell and Gibbs, and Jolly and Cornwall. Stella Nyanzi's discussion (Chapter 31) is also on The Gambia and touches upon sexuality, but concentrates more on male youths and particularly their homosocial strategies for survival in a context where high levels of unemployment are associated with widespread aspirations to overseas migration.

The last four chapters in this part consider various aspects of gender and poverty in old age, which has hitherto been a rather neglected issue. The particular focus of Isabella Aboderin's chapter (Chapter 32) is Ghana where she draws the possibly counterintuitive finding that older women tend to fare better than older men on account of their prior and/or ongoing emotional, labour and financial investments in their children. Although Aboderin notes that similar patterns have been found in other countries such as Costa Rica, this is not always the case, as demonstrated by Penny Vera-Sanso (Chapter 33) for Chennai, India, where in addition to filial support (or its erosion), pensions (which include means-tested non-contributory schemes) do relatively little to redress gender inequalities in old age. In Chennai older women appear to be multiply disadvantaged on a number of counts. Not only do more women than men end up destitute because women tend to live longer than men (although premature mortality is often a corollary of their poverty), but because women are less likely to accumulate earnings or pension advantages over the lifecourse, and because of prevailing social perceptions that the old need fewer resources than the young, and women less than men.

Monica Budowski's comparative discussion of multi-pillar pension models in Chile and Costa Rica (Chapter 34), where the decline of normative expectations, and actual practices of family support have made pensions absolutely critical for women and men 
to survive in later life, reflects inter alia on how privileges in pension policies for elderly women (as mandated by recent Chilean reforms), can institutionalise gender differences. By the same token, Jane Falkingham, Maria Evandrou and Athina Vlachantoni (Chapter 35 ) in relation to the UK, defend the importance of recent moves to acknowledge women's caring responsibilities, even if the low value of disbursements remains a concern.

In Part IV, attention turns to aspects of gendered poverty in which questions of 'race' and migration feature prominently, and often in conjunction with one another given the growing incidence of demographic mobility within and across borders.

On the subject of 'race' per se, the first chapter in this part, by Janet Hunt (Chapter 36), considers questions of how to assess poverty, gender and well-being among indigenous communities of the Global North - particularly Australia, Canada and New Zealand - where different meanings and priorities often hold sway among 'mainstream' and 'marginalised' populations.

Notwithstanding the problems attached to who defines the needs of indigenous peoples and how, Mercedes González de la Rocha's discussion (Chapter 37) finds some interesting and encouraging results for indigenous women of the high-profile Mexican CCT programme Progresa-Oportunidades, which, after more than ten years' duration, offers substantial potential for evaluating long-term and sustainable outcomes. Although this programme is not specifically tailored to Mexico's indigenous populations, its cash transfers provide a source of regular income to groups traditionally deprived in terms of schooling and who suffer precarious positioning in the labour market. Moreover, the unprecedented opportunity for indigenous girls to progress with their education is regarded as a vital route to improve well-being in future. These positive findings go somewhat against the grain of other analyses (see earlier), and thereby bring to bear the importance of intersectional analysis and differentiation among women.

Also on Latin America, Helen Safa's second contribution to the Handbook (Chapter 38) considers questions of gender, poverty and national identity in the context of a comparative analysis of indigenous and afrodescendent groups in the region. Among Safa's principal findings is the particularly strong social, economic and political role of afrodescendent women. This has not only been forced by conditions of greater racial marginalisation than faced by indigenous populations, but also through wider diasporic movements in which women have participated either as migrants in their own right, or as the managers of remittances.

Interesting gender dynamics of international migration are further pinpointed by Cathy McIlwaine (Chapter 39) in the context of her detailed fieldwork among Latin American migrants in London which reveals a complex and often contradictory tapestry of genderdifferentiated 'exclusions'. At one level migrant men deem themselves marginalised by their lack of access to jobs which are routinely associated with the preferential recruitment of women, or because of their consignment to menial, 'feminised', occupations. Yet at another level, men's privileges in respect of legal status, gender divisions of reproductive labour, and questions of social identity, collude to maintain male-female hierarchies.

Questions of women's access to low-wage - and even 'recession-proof' - servile jobs, along with women's disproportionate 'liminal legality', also form a substantial part of Cecilia Menjívar's analysis of Central American migrants to the USA (Chapter 40), wherein she finds that changes in daily practices among women and men do not necessarily destabilise inequitable gender ideologies. 
In many senses similar patterns are found by Claire Alexander (Chapter 41) in her study of the UK. Although this discussion mainly focuses on Asian-Muslim young men in the context of the 'war on terror', and their progressive marking as emblematic of 'imagined national, racial and cultural crisis', Alexander also demonstrates the injurious ways in which Asian-Muslim women encounter discrimination in their own 'enclaves' as well as in wider British society which has major implications for their social, political and economic positioning and agency.

The succeeding chapter, by Linda McDowell (Chapter 42), considers from a more historical perspective the gender dynamics of 'race' and international migration from the relatively under-studied context of Latvia, which in the 1940s underwent a 'double' occupation by Soviet and Nazi German armed forces. This gave rise to a variety of movements, including the migration of some young women to the UK. Such displacements not only disrupted conventional lifecourse transitions, but were often associated with significant downward mobility.

The extent to which the forfeit of accepted social norms - and the costs of these - is a corollary of intra-national migration is explored in various degrees in the three chapters in this part which deal primarily with gendered mobility within national borders. The review by Haydea Izazola (Chapter 43), for example, on gender, poverty and migration in Mexico, although touching upon gender-selective international as well as national migration, reports diverse implications for women 'left behind' in source areas. On one hand the latter may benefit from greater income security and enhancement, and even more power and autonomy. However, others are condemned to greater vulnerability, especially where remittances from migrant spouses dry up, often without forewarning.

In the chapter by Daniel Jordan Smith (Chapter 44), on the migration by young Igbo women to the northern Nigerian city of Kano, the contradictory corollaries of - in this case - female-selective migration are highlighted through evidence of trade-offs between moral and material currencies negotiated by young women in their pursuit of pathways out of poverty.

The chapter by Cecilia Tacoli (Chapter 45), which focuses on internal migration not only in Nigeria, but also Mali,Tanzania and Vietnam, reveals how mobility and the move away from 'traditional' rural economies and societal values has increased in recent years. At one level this reflects women's ongoing disadvantage in land acquisition and inheritance in rural areas. However, new patterns are also fuelled by the opening up of spaces for women in urban labour markets, and the drive among young women to assert independence, even if one price to be paid is heavier obligations of support to natal kin.

The final chapter in this part, by Kalpana Wilson (Chapter 46), entitled 'Picturing gender and poverty: from "victimhood" to "agency", expounds on the changing representation of racial 'minority' women in the Majority World in development discourse and campaign documentation - an issue which also features in the later chapters by Roy, Richey and Jassey. ${ }^{7}$

In Part V, a fairly small, but vital, series of issues relating to 'Gender, Health and Poverty' are addressed from a range of perspectives. In the opening chapter (Chapter 47) Jasmine Gideon discusses gender, poverty and the right to health with particular reference to Chile, one of several countries in the world whose pronounced marketisation and commodification of healthcare carries deep gender implications. For example, in Chile's new neoliberal provision model, women have less 'ability to pay' than men, have to pick 
up the cudgels for the 'return' of vital reproductive and care services to the home, and on top of this are increasingly having to make ends meet through labour force insertion, predominantly in the informal economy. Over and above the additional strains on women's labour, time and bodies, that few jobs offer prospects of private health insurance poses threats to their well-being.

Anna Coates's second contribution to the Handbook (Chapter 48) considers the wider Latin American scenario in specific relation to the reduction of maternal mortality, which has qualified as a goal in its own right on the MDG agenda. Although maternal mortality rates (MMR) are lower in Latin America than other regions of the Global South, at a sub-regional level there are marked inequalities related to poverty and ethnicity, which have been deemed tantamount to a form of gender violence against poor, minority mothers.

Although women are often the main victims of inadequate, class-biased healthcare, a rather different scenario is painted in Matthew Gutmann's chapter (Chapter 49) which branches into one of the biggest contemporary global health issues: HIV/AIDS. Set in the context of the Oaxaca, southern Mexico, where poverty has increasingly driven men to engage in cross-border migration to the USA, Gutmann reveals how this has led to men having the highest rates of HIV infection in the state. Men's exposure to the disease seems to be linked with casual sexual encounters forced by loneliness during their time away from home. The social stigmatisation and inadequate public health responses which greet them on their return do little to improve the situation for migrant men, not to mention the female sexual partners that they infect.

The disadvantaged position of men in respect of treatment, even in contexts such as South Africa where, unlike in Mexico, the drugs used in anti-retroviral therapy (ART) can be purchased at less than market price, is echoed in the chapter by Catherine Campbell and Andrew Gibbs (Chapter 50). Yet in this discussion, we also learn that although, in the heartland of the epidemic in SSA, HIV/AIDS has historically been associated with populations who are 'affluent, educated and mobile', poverty and inequality have begun to transfer new infections to poor young women, often as a result of the socio-economic inequalities associated with 'transactional sex'. Thus while women are more likely to be diagnosed early and to receive treatment - partly because of their greater engagement with healthcare services through pregnancy and children - the majority ( 60 per cent) of new HIV-cases in the region are female. ${ }^{8}$

Another issue raised by Campbell and Gibbs - that of gender bias in carework for people living with HIV/AIDS (PLWHA) - receives more dedicated treatment by Keerty Nakray (Chapter 51) in the context of India, which is one of the countries outside SSA where new rates of HIV infection are on an alarming rise. The disjunctures between the rights and rewards of women carers in respect of marginalisation and eviction - even when they themselves are ill, and often due to infection by husbands who did not disclose their HIV-positive status - constitute persuasive grounds for policy interventions to recognise and support these new feminised burdens borne by 'housewives', and not just to target groups commonly perceived to be most 'at risk'.

The final chapter in this part, by Hilary Graham (Chapter 52), with particular reference to the UK, deals with a health-related issue - smoking - historically associated with 'risk-taking' activity among elite men, but which is in the process of becoming a major concern among poor women in advanced economies. In Graham's opinion, this requires 
interventions which go well beyond standard medical anti-smoking campaigns, to those which address social disadvantage and inequality.

The relatively uncharted but immensely significant issue of 'Gender, Poverty and Assets' forms the subject of Part VI. This starts with a chapter from Carmen Diana Deere (Chapter 53), who outlines some of the principal conceptual and methodological factors in assessing gender inequalities in asset ownership. Deere reveals the critical role of these in shedding light on intrahousehold disparities, and how the valuation of assets (in addition to working out the share of this accruing to women who own assets jointly as well as independently) is critical in assessing gender-differentiated poverty. On the basis of her exploration of Latin American data, Deere points out that the biggest asset gap between women and men is land. This is echoed for cities of the Global South more generally in the chapter by Carole Rakodi (Chapter 54), with particular complexities noted here on account of the fact that a major share of land and property ownership is of an 'informal' nature.

Continuing in a similar, although more context-specific vein, is a chapter by Kate Bird and Jessica Espey (Chapter 55) on women's land rights in two 'post-conflict' environments: Uganda and Rwanda. Here they contend that 'gender blindspots' in policies and legislation around land are likely to leave poor women disempowered to change their situations, which echoes Koster's arguments in relation to asset poverty in Rwanda.

Another set of perspectives on questions of land and property is drawn out in Sunil Kumar's chapter on gender, livelihoods and rental housing markets in the Global South (Chapter 56). While Kumar's discussion shows that women are often as disadvantaged in rental tenure as in owner-occupation, he also points up the economic potential for women who are able to let out parts of their dwellings or compounds in contexts where other livelihood opportunities are in limited supply.

Also on the matter of housing, Sophie Mills's discussion of women's access to shelter microfinance in South Africa reveals the potentially transformative personal and public impacts of housing credits directed to women (Chapter 57). Yet although on one hand these can bolster women's bargaining power and 'fallback' position, Mills reminds us that housing may also be a 'problematic asset' insofar as it can imply greater burdens of female responsibility for non-contributing household members.

In another housing-related chapter, Sheela Patel and Diana Mitlin (Chapter 58) report on the critical role of women in 'feminising' the agenda and interventions of grassroots organisations such as the now internationally networked Shack/Slum Dweller Federation. This has not only raised the profile of women's concerns in low-income settlements, but has also led to a more prominent political role for women in local governance.

Turning to other types of 'assets', such as social capital, Katie Willis's chapter (Chapter 59) on Oaxaca City, Mexico, explores the differential access by women (and particularly female-headed households) to this vital resource according to socio-economic status. Willis warns that for poorer women - whose needs are arguably greatest - the supply of social capital is limited both by a combination of lack of contacts and time, such that caution needs to be exercised by development agencies who assume that this can be mobilised by the poor at will.

Caroline Moser's chapter (Chapter 60) looks not only at the importance of social, human, physical and other assets, but also at their accumulation over time, in the context of over thirty years' detailed ethnographic research in a low-income settlement built on reclaimed swampland in Guayaquil, Ecuador. From these inauspicious beginnings, 
many households have been successful in strengthening their asset portfolios, most recently through international migration among younger generations. Again there is evidence that even if female-headed households may not be income-poor in comparison with male-headed units, their relative asset poverty begs questions about the processes which lead to this outcome.

While Moser's chapter covers an extensive range of assets, so too does the final chapter in this part, by Rachel Slater, Rebecca Holmes, Nicola Jones and Matšeliso Mphale (Chapter 61). On the basis of a pilot study in Lesotho, these authors stress the importance of taking into account social as well as economic vulnerability for shaping social protection measures to reduce gender inequalities and to promote women's empowerment.

The conclusions of Slater et al. are extremely important for Part VII, on 'Gender, Poverty and Work', where we take a detailed look at one of the biggest assets of all households, and perhaps particularly the poor: labour (González de la Rocha, 2006b, 2007; Moser, 1998). Although this section might conceivably have come earlier in the Handbook, I chose to place it later on to disrupt something of the tendency for gender inequalities in employment to be given the lion's share of attention in analyses of gender and poverty - mainly through the association with income and pay gaps - when the origins, emanation, character and impacts of gendered poverty occur in so many other forms and spaces. As it is, the diverse discussions in this part serve to highlight that gender inequalities in work and their interrelationships with poverty require analyses which go far beyond cursory treatment of labour markets per se. As summarised by James Heintz in his chapter on women's employment, economic risk and poverty reduction (Chapter 66): 'an exclusive focus on the market relationships that govern employment dynamics ignores non-market activities that have an enormous effect on poverty status, development outcomes, and the production of human potential'. For example, although occupational segmentation and segregation play a major role in accounting for gendered earning differentials, as discussed by Janneke Plantenga and Eva Fransen (Chapter 63) in the context of Europe, and by Amy Liu for Vietnam (Chapter 69), it is impossible to understand why and how employment divisions come about without reference to the embeddedness of gendered processes within global capitalist production and accumulation (as discussed, inter alia, by Ruth Pearson, Chapter 64, in relation to the most dynamic sectors of the global economy [including information and communications technology/ICT], by Stephanie Barrientos, Chapter 67, with respect to Global Value Chains, by Sharad Chari, Chapter 68, in relation to the feminisation of industrial labour in one of India's hubs of garment exports, Tiruppur, and by Marty Chen, Chapter 71, and Kate Meagher, Chapter 72 whose chapters touch upon the links between economic globalisation and informal work.

Integral to gender inequalities in different economic sectors - and at different scales - is the interplay of markets with states and households. For example, Katherine Brickell's chapter on Cambodia's post-conflict transition to a market economy (Chapter 70) points to the various tensions posed by women's designation by the state as 'precious gems' in the new economic model, and their roles in managing household poverty burdens, while their paid labour in the emerging tourism sector, and on construction sites, continues to be regarded as secondary to the work of men, and is often a source of conflict within the home. More generally, and with reference to a range of countries in the Global North and Global South, Shahra Razavi and Silke Staab (Chapter 65) indicate how states play a 
massive role in mediating the links between households and labour markets through programmes of social assistance and fiscal policy (tax and transfers). These are especially relevant to women workers whose degree and type of economic activity is strongly influenced by claims on their unpaid household labour, and its social and symbolic corollaries.

As with this latter contribution, a thread running through most of the chapters in this part is the question of the fundamental factors underpinning persistent labour force divisions. One crucial factor, highlighted, inter alia, by Diane Perrons (Chapter 62) in relation to high-income economies, is that the continued bias of unpaid care and reproductive labour towards women, in the absence of effective public support for unpaid carework, not only restrains many women's access to well-paid employment, but also leads to clusters of feminised jobs in areas of the service economy (often in care services per se) which are undervalued and underpaid, both at national and international levels.

Low-paid, part-time, precarious and undervalued work, often on the margins of the formal economy, is a common predicament for women in advanced economies. As the chapters by Perrons and others in this part show, the demands of women's domestic roles frequently force them to prioritise hours and location above occupation and pay, and once they are in the part-time/flexible sector it becomes difficult to escape, with major impacts on their lifetime earnings. ${ }^{9}$ Yet in developing regions, where between one-half and three-quarters of the labour force is informally employed, the situation is arguably worse still. Informal employment is generally associated with lower incomes (Heintz, Chapter 66), and as Chen points out, sources of informal work are not only generally more significant than formal jobs, as well as a larger source of employment for women than men, but women are also usually found in the lower echelons of the informal economy. Paramount here, then, is Meagher's question about whether informal employment, so often regarded as a positive means of accommodating women's needs to balance income-generating work with reproductive responsibilities, is a source of 'impoverishment' rather than 'empowerment'.

The issue of employment status - which refers to the degree of autonomy one has in employment, including brokers and intermediaries in subcontracted or self-employment, or what Heintz refers to as the 'quasi labour market' - is also critical here. This is discussed in relation to Colombia and other parts of Latin America with reference to 'quality of work' by Javier Pineda (Chapter 74), and in the context of Surat, India by Paula Kantor (Chapter 73), who explores gender-differentiated deficits in 'decent work' as defined by the International Labour Organisation (ILO) which in 1999 launched its agenda for more and better quality jobs.

The significance of examining the links between gendered labour divisions and poverty in the twenty-first century is arguably more important than ever, when, as Heintz notes, more women are undertaking income-generating activity during an epoch in which increased demands are made on their unpaid work as a result of social expenditure cuts. Yet despite a backdrop of declining access to regular, guaranteed, full-time employment, Heintz cautions against unproblematised connections between the 'feminisation of labour' and the 'feminisation of poverty', even if, as the simulation performed by Joana Costa and Elydia Silva for Latin America (Chapter 75) reveals, a reduction of gender inequalities in the labour market would go a long way to reducing poverty.

Another consideration relevant to this debate is that the links between employment and poverty are not as readily assessed as they may first appear. Corroborating the 
discussions by Heintz (Chapter 66) and Razavi and Staab (Chapter 65), Chen (Chapter 71) points up how employment is measured at an individual level, whereas poverty is routinely calculated at the household level. Bridging this hiatus, a new technique noted by Chen, devised originally by UNIFEM, is to assess household poverty risk on the basis of the proportion of members employed in different kinds of work. Even then, questions of intrahousehold income pooling, control and resource allocation also need to be more closely scrutinised in order to determine the risk of poverty among different women and men, as further discussed by Meagher (Chapter 72) with reference to sub-Saharan Africa, as well as by Heintz, and by Razavi and Staab.

Given the diverse factors affecting gender divisions in formal and informal employment at different scales, it is no surprise that the policy agendas proposed by authors are extremely heterogeneous. Nevertheless, there is broad consensus that a major step towards rectifying gendered labour market disadvantage and creating more 'decent work' for women in the spirit of ILO directives would be a proper economic valuation of the unpaid work which women routinely perform, and more national recognition and spending on appropriate support facilities for mothers and unpaid carers. From the standpoint that social policies to date have rarely measured up to the task of compensating 'labour market losers' (Chen, Chapter 71; Razavi and Staab, Chapter 65), comprehensive packages, over and above more adequate childcare support, might include the creation or more, better quality, and less gender-segregated job opportunities, gender-sensitive wage policies, more gender-responsive social protection (pensions and so forth), and increased access to credit and training. In the context of informal employment specifically, Chen proposes a ' $3 \mathrm{~V}$ ' framework encompassing 'Voice, Visibility and Validity', which makes visible the participation of women workers, recognises and validates them, and ensures their better representation in labour market institutions. A parallel discussion in Perrons' chapter on high-income economies with greater levels of regulated employment includes a more extended version of this model based on the work of Damian Grimshaw and Jill Rubery (2007). This identifies five 'V's with rather different nomenclature and referencing points. One of these is vocation, which pertains to the tendency for particular kinds of work to be attributed to women's 'natural talents' rather than skills. Another is variance, which relates primarily to the over-representation of women in part-time employment which confines them to a narrower range of sectors and occupations.

Questions of working conditions and 'quality of work', will also require the extension of ILO core standards to women engaged in seasonal, casual, homework, migrant labour and contract work in export production. This is a particular focus of Barrientos's chapter (Chapter 67), which also notes the potential pressure that can be brought to bear by consumers in the Global North to protect workers at the lowest end of Global Value Chains (GVCs) in developing nations.

Another potentially critical factor is that employment should feature more prominently in the MDG agenda, which as Chen and Kantor note has until recently remained conspicuous by its absence, notwithstanding one major recommendation by the United Nations Millennium Project's Taskforce on Education and Gender Equality (UNMP/ TFEGE, 2005) that steps are taken to reduce women's reliance on poor quality informal work within the paid economy (Meagher). ${ }^{10}$

Building on some of the policy recommendations made in relation to employment, in Part VIII we move into the broader field of 'Gendered Poverty and Policy Interventions', 
in which the tensions between genuine bids to promote gender equality and empower women through poverty reduction are arguably among their most visible in the Handbook. One issue covered in this part of the volume is aid. This comprises discussions that range from the fleshing out of the possible implications for gender of new forms of 'aid architecture' in the wake of the 2005 Paris Declaration which, inter alia, devolves more determination over aid expenditure to recipient states (Gwendolyn Beetham, Chapter 76), to the stranglehold over aid priorities and mediation by people far-removed from the everyday life of their intended beneficiaries (Katja Jassey, Chapter 78 and Lisa Ann Richey, Chapter 77). Both the latter authors reflect on the motives of aid-givers as well as the portrayal of, and outcomes for receivers. While Jassey's discussion explores, inter alia, why the policy agenda of the Swedish International Development Agency (Sida) continues to be dominated by 'poor brown women', usually constructed as 'downtrodden helpless victims', Richey's chapter focuses on the new celebrity-driven development initiative 'Product Red ${ }^{\mathrm{TM}}$ '. The latter sees corporates dedicating a slice of profits from certain of their 'Red-branded' products to the Global Fund to Fight AIDS, Malaria and Tuberculosis. Although the conditions under which Red products are actually elaborated may not always stand up to the test of scrutiny, Richey levels that this initiative has contributed to converting 'consumption into a mechanism for compassion', affording opportunities for 'low cost heroism' to shoppers in the Global North, not to mention the 'stars' who feature in the campaign media.

But policy interventions are not solely driven by external actors: 'poor women' themselves (or through their representation by politically elected individuals and civil society groups) are nominally able to exert more agency in policy initiatives which on the surface require greater and more polycentric 'stakeholder' involvement. Classic examples include gender-responsive budgeting (GRB), which has been road-tested in an increasingly widespread range of countries in the Global North and Global South (Diane Elson and Rhonda Sharp, Chapter 80), and programmes guided by Poverty Reduction Strategy Papers (PRSPs) adopted by poor countries seeking debt relief (Sarah Bradshaw and Brian Linneker, Chapter 79) in which gender is purportedly a 'cross-cutting' issue. Although, as Bradshaw and Linneker point out, the PRSP process has evolved in the context of a 'new era' in which international financial institutions (IFIs) are concerned with poverty as well as growth, and nominally committed to broad-based consultation and consensus, in reality the amount of input by poor women to policy design and delivery is minimal. In turn, the CCT programmes often linked with PRSP initiatives tend to narrowly link women's poverty issues to their roles as mothers (see earlier). While GRB offers a more positive scenario, ensuring greater transparency and accountability in public expenditure, and that at least a proportion of this gets allotted in pro-gender equality and propoor ways, Elson and Sharp caution that the amounts are too small to make GRB a stand-alone panacea for poverty. Similar conclusions in relation to the slightly different context of targeted anti-poverty programmes for women and female household heads in Costa Rica are reached by Monica Budowski and Laura Guzmán Stein (Chapter 81), who reiterate the need for a range of interventions to overcome gendered poverty.

Interesting light on gendered poverty interventions is presented from the vantage points of two northern development NGOs (NDNGOs), Oxfam GB (Nicholas Piálek, Chapter 82) and WOMANKIND Worldwide (Tina Wallace and Ceri Hayes, Chapter 83), both of which have a strong commitment to learning from their partners. 
While Wallace and Hayes point up how WOMANKIND's work is often compromised by short-termism, and increasing pressure from major donors for demonstrable results (something also emphasised by Jassey in relation to her discussion of Sida), both WOMANKIND and Oxfam have been at the forefront of working with multidimensional concepts of gendered poverty. In the specific case of Oxfam, Piálek traces the evolution of discourses within the organisation from regarding gender inequality as a compounding factor in poverty, to a type of poverty itself, meriting action in its own right.

Touching upon many of the arguments in this section, the concluding chapter by Ananya Roy (Chapter 84), entitled 'Millennial woman: the gender order of development', reinforces the observation that gender has become increasingly 'yoked' to poverty, and discerns what she calls a 'financialisation of the poverty agenda' in which women are often positioned at the forefront. This increasingly entails the depiction in development documentation and imagery of women as happy and productive entrepreneurs (as also described by Wilson in Chapter 46), which are harnessed to the 'technofinancial infrastructure of the new millennium' through microcredit initiatives in their various guises, as discussed in the next and ninth part of the Handbook.

I decided to create a separate part on 'Microfinance and Women's Empowerment' because microcredit stands out as one of the most obviously gender-specific types of contemporary policy interventions - particularly in developing countries - and to which the UN has now seen fit to dedicate a special year. ${ }^{11}$

Despite the particular relevance of microfinance to the Global South, Beverly Lemire's opening chapter in Part IX (Chapter 85) draws attention to the centuries' importance of women's roles in underpinning household survival. This has taken the form in Europe, and elsewhere, of women acting as brokers between the household and the market through personal, local and more public thrift and savings initiatives, including the lending of money to one another, and the guaranteeing of loans. The common emphasis in microfinance schemes on group loans is, as Kate Maclean (Chapter 87) discusses in relation to twenty-first century Bolivia, often a perceived and actual way in which microcredit organisations can guard against risk of default and ensure their own survival. Yet to use Maclean's expression 'capitalising on women's social capital', drawing on relationships of support and reciprocity which women are already actively engaged in building, may not be in the best interests of women clients or 'beneficiaries' insofar as it can exert immense pressure upon them to sacrifice their own well-being to keep up repayments. Indeed, the question of whether poor women are necessarily inclined to join forces in their bids to exit poverty is one in which general assumptions are ill-advised. On one hand, Bart Casier's discussion of microfinance in The Gambia and Senegal (Chapter 94) reveals that individual business growth appears to be less important to women recipients of credit than (re) investing the proceeds of entrepreneurial ventures in infrastructure which benefits the community as a whole. However, another scenario is revealed in Caroline Sweetman's discussion of Addis Ababa, Ethiopia (Chapter 88), which raises the issue that strategising for economic advancement beyond women's own households is something of an anathema in this context. As further highlighted by Supriya Garikipati in her discussion of the Self Help Group (SHG) Bank Linkage Programme in India (Chapter 92), women may not actually be in a position to use their loans even for investment in personally-owned assets. Thus while Ranjula Bali Swain's discussion of the same 
programme (Chapter 91) contends that women who receive credit through the SHG scheme are more 'empowered' than non-clients, Garikipati, in the context of South India, echoing Sweetman's observations in Ethiopia, errs towards the conclusion women's participation can often result in their 'disempowerment', through a hefty 'feminisation of debt' which requires more self-exploitation, and sometimes a widening of gendered gaps in well-being.

Questions of collective versus individual interests aside, a number of chapters in this section such as those of Iman Bibars on Egypt (Chapter 89) and Fauzia Mohamed on Tanzania (Chapter 86), as well as some already mentioned (Casier, and Sweetman, for example) stress how microfinance can make some inroads to reducing poverty - mainly because it allows women to 'smooth-out' fluctuations in household income - but is ineffective at providing a pathway out of gendered poverty. Obstacles here include the small size of loans, insufficient attention on the part of implementing institutions to the gendered structures of constraint which act to limit women's personal autonomy, lack of specialist orientation in enterprise growth, and the fact that there is insufficient dynamism in the local or even macroeconomic contexts in which women operate to allow for truly successful business ventures. These factors are noted not only by Casier for Senegal and The Gambia (Chapter 94), but by Irene Banda Mutalima in relation to Zambia (Chapter 93), who points up the contradictions posed by the poverty-reducing social missions of microfinance institutions (MFIs) and the need for the latter to ensure their own viability in an increasingly competitive context of donor funding. An additional point, raised by Joanne Sharp, John Briggs, Hoda Yacoub and Nabila Hamed (Chapter 90) in the context of microfinance interventions among the Bedouin in southeast Egypt, is that until microcredit projects prove to be successful, they tend to be residualised and to be regarded of little worth by better-off members of the community. Thus, while on balance many MFIs may enjoy high rates of on-time repayments and rich returns on their investments, including capital growth, whether an escape from poverty, and the enhancement of women's individual well-being, form part of this scenario are less assured (Casier, Chapter 94 and Maclean, Chapter 87). The issue of whether microfinance provides a route towards female empowerment also remains a moot point, with Mohamed (Chapter 86), inter alia, stressing the need for a range of ancillary interventions such as reforms in education and legal systems.

Last but not least, the question of how women's empowerment may be measured is taken up briefly by Bali Swain (Chapter 91), and in more depth by Yoko Fujikake in the closing chapter of this part (Chapter 95). Introducing her own 'empowerment evaluation' model developed in Paraguay, Fujikake highlights how methodologies and frameworks which give rounded consideration to processes and outcomes may require substantial inputs of time and expenditure on the part of development organisations, as well as to be validated and/or adjusted in other contexts.

The title of the tenth and concluding part of the Handbook - 'New Frontiers in Gendered Poverty Research and Analysis' - is not intended to detract from the pioneering nature of many of the preceding discussions (with which there is often considerable overlap), but was chosen partly because the chapters deal explicitly with issues which either represent some of the newest bodies of research on gendered poverty or which are comparatively recent in their appearance on policy agendas.

In Sarah Bradshaw's discussion of disaster relief (Chapter 96), through the lens of 
Hurricane Mitch in Nicaragua, it appears that the cart has come somewhat before the horse. Despite relatively little empirical investigation into the gender-differentiated impacts of disaster, assumptions about the comparative poverty of women - and about their roles and dispositions within communities - seem to have led to a 'feminisation of post-disaster responses' in which there appears to have been a co-option of the same kind of 'feminisation of responsibility' logic observed in anti-poverty programmes in general. Moreover, while Bradshaw notes that the allocation of resources to women and femaleheaded households can secure material gains, this may not necessarily leave them with a greater sense of well-being or self-worth.

A pervasive 'feminisation of responsibility' is also apparent in the context of a clutch of chapters which deal with varying aspects of women's community and public roles in the context of neoliberalism and the 'democratisation' of local and national politics Although the mobilisation of women in defence of household, neighbourhood and, even, city-wide survival was observed during the era of recession and structural adjustment in the 1980s, ongoing processes of decentralisation and the encroaching of new 'rights-based agendas' in local-level governance have been critical in the opening up of new political spaces. In the context of India and South Africa, which Jo Beall (Chapter 97) highlights as among the countries in which most progress has been made towards the representation of women on decision-making bodies, 'presence matters' insofar as this has been associated with greater likelihood that issues of crucial relevance to women's daily lives, such as basic services and infrastructure, are prioritised. This is echoed by Sumi Madhok (Chapter 98) in the context of what she terms 'vernacular rights cultures' in her case study of India, and by Faranak Miraftab (Chapter 99), with reference to contradictions in the 'gender-poverty nexus' in South African townships. However, one major concern, summarised cogently by Beall is that 'the pursuit of decentralisation and women's rights does not become a vehicle for putting a human face on neoliberal preoccupations with privatisation, deregulation and cost recovery at the expense of poor women'. Similar doubts are aired by Amy Lind (Chapter 100) in relation to her (re)assessment of the institutionalisation of women's struggles for survival in the neoliberal (and postneoliberal) contexts of Venezuela and Ecuador. Despite the alternative development paths offered by the more left-wing governments elected in these countries in 1999 and 2006 respectively, and a greater degree of political participation by women, traditional heteronormative maternalist assumptions continue to hold considerable sway. This translates into women's continued framing as the main 'problem-solvers' for poverty in their households and communities, and, more insidiously, as the vanguard in compensating for weak welfare states. A fundamental rethinking of the contemporary family is one of the main ways forward stressed by Lind.

On a more positive note, Alissa Trotz's discussion of the experience of the grassroots women's organisation 'Red Thread' (Chapter 101) echoes some of the more encouraging examples from India and South Africa highlighted in the chapters by Beall, Madhok and Miraftab, whereby women's active involvement not only in protest and demand-making, but also in undertaking surveys which have involved recording the labour performed by women, has been critical in sharpening women's visibility to one another, and fomenting linkages across different 'race' groups in the country.

Another 'new frontier' in gendered poverty analysis is that of religion, with Claire Brickell's chapter on Albania (Chapter 102) pointing up the contradictions posed for 
women's 'empowerment' by 'external' faith-based organisations (FBDOs), specifically that of an Evangelical Christian charity, in the low-income community of Bathore on the outkirts of the capital, Tirana. While concentrating mainly on the dangers embodied in prescriptions for female empowerment infused with patriarchal religious dictates, Brickell's discussion raises the more general question about how far short-term solutions to addressing women's daily experiences of gendered poverty can go to addressing their underlying causes.

Taking up a theme covered in the context of a number of case studies earlier in the volume (for example, Evans, Lind, Moore, Williams), the chapter by Susie Jolly and Andrea Cornwall (Chapter 103) summarises more generally the increasingly recognised importance of sexuality within discussions of gender, poverty and development. This highlights, inter alia, the threats that sexual ill-health present to security, economic growth and human well-being, and how various forms of poverty - broadly-defined - are faced by those whose sexual preferences, practices and pleasures are marginal to dominant norms and forms.

Last but not least, Jane Parpart's closing chapter on 'Masculinity, poverty and the "new wars"" (Chapter 104) speaks to the issue of post-Cold War violence, mainly in the context of fragile sub-Saharan African states. Here conflicts, in which systematic forms of gendered violence - including sexual brutality - are frequently integral, appear to be driven substantially, if not exclusively, by economic inequalities and poverty. Young men are often readily recruited into 'new war' regiments because this is their only way of making a livelihood and garnering some kind of social recognition and stability. Although some women are also admitted into these ranks as 'foot soldiers', their lot is more usually one of abuse and disempowerment. Among one of the biggest priorities for the world at large, therefore, is that attention is paid to the gendered needs and anxieties suffered by women and men, in and out of combat, in the struggle to create a more effective and enduring 'liberal peace'.

\section{A final word}

While the chapters introduced above cover most of the main ground appropriate to a benchmark book on the subject of gender and poverty at the end of the first twenty-first century decade, all countries are undergoing new threats as a result of the global financial crisis whose historical recency precludes more than speculative thoughts about the ways that this will impact women and men in the future. On top of this, there is the contentious matter of climate change which is deeply implicated in world economic development and poverty, but until the last few years has been considered mainly from a scientific rather than a social perspective, and has left the possible gender ramifications largely uncharted (see Demetriades and Esplen, 2008). In this current - and potentially cataclysmic - global economic and environmental context, demonstrated so poignantly by the January 2010 earthquake in Haiti and the disturbing surge in sexual violence against women in its aftermath, a number of pressing questions for gender must form part of upcoming academic and policy agendas. For example, how will poor women and men cope with the costs of climate change when it is commonly thought that the poor have less 'adaptive capacity' than wealthier groups, and that although women may be worse affected and perceive and prospectively react differently to men, their often circumscribed powers of negotiation within households and communities may prevent them from exercising 
defensive strategies? (ibid.; see also PEP, 2003; Tanner and Mitchell, 2008). ${ }^{12}$ How will subsidised microcredit loans to low-income women pan out in a situation in which banks in general struggle to regain profits, as well as trust and confidence? What is to be done vis-à-vis welfare, poverty reduction and environmental protection programmes when the contraction of economic growth undermines the resources conventionally made available through tax and transfers to 'social' expenditure? What new gender dynamics are likely to present themselves in a context in which men have even greater difficulties in fulfilling normative expectations of economic provision, and in which women are likely to receive even less public support for their endeavours to manage poverty burdens within their households and communities? What space is likely to be afforded to the intersections of gender with other crucial issues such as age, sexuality, migrant status, class, and so on, when the prospective 'flattening' of economic growth is likely to plunge the world into a recession of a magnitude not witnessed for several decades, despite an incredible accumulation of wealth on the part of a few? There is already evidence of international remittance income 'drying up' as recession hits vulnerable workers on the margins of economies in the Global North, which, given the hitherto mounting role of private transfers in propping-up survival in southern countries as aid budgets have fallen, bodes ominously for poorer countries in the world. ${ }^{13}$ These kinds of questions are not only signalled by a number of contributors to the Handbook, but in other contemporary writings, and, as identified earlier, by one of the biggest international feminist networks (DAWN) (see note 3). Does this historical juncture represent, as DAWN and others hope, a new - and potentially productive moment - in which to rethink the operation of global and national economic systems? To what extent does an opportunity now present itself to devise policies which build on the time-honoured attempts of academics, activists and policymakers to create a more just world order in which polarities are evened out, and women and men come to enjoy being part of a global community in which compassion, cooperation and collective responsibility supercede competition? Although many of these issues are too new to the scene to warrant definitive, or maybe even vaguely informed, predictions, this Handbook lays some critical foundations and a knowledge base for research and policy which I strongly hope are taken further in the second millennial decade and beyond.

\section{Acknowledgements}

I am extremely grateful to Sarah Bradshaw, Gwendolyn Beetham, Bart Casier, Alice Evans, Amy Hause, Lee Mager, Diane Perrons, Cecilia Tacoli and Carolyn Williams for their valuable comments on this chapter.

\section{Notes}

1. In the interests of scoping out this Handbook, I have flouted my own regulations on word length and a maximum of seven bibliographic items per chapter. These were rigidly imposed on all authors (including in relation to my own case study contribution on the 'feminisation of poverty'). In these restrained circumstances, contributors were encouraged to include in their 'select bibliographies' key sources cited in their chapters in which more fully referenced discussions could be consulted. Although my introductory bibliography here is not quite as 'select' as in the body of the volume, I have adopted a minimalist approach, and apologies are offered to those authors who with freer rein would certainly have been acknowledged. At least a good number of them will find their vital contributions to the field cited elsewhere in the Handbook.

2. That the level was likely to rise is extremely doubtful given the tenuous nature of the baseline. Aside from lack of robust empirical evidence, for example, Alain Marcoux (1998a, 1998b) points out that the 70 per 
cent share of poverty purportedly borne by women in 1995 is implausible in light of the age distribution of the global population (even at the time of a comparatively more youthful global population), and its household characteristics. Even assuming a priori that being female places persons at a greater risk of being poor, given that the sex of children under 15 is unlikely to have more than a negligible impact on gender differentials in household poverty, only single person and lone parent units could be responsible for the excess of female poverty. Yet there are simply not enough households of this type to give rise to the purported 70/30 ratio of poor women and girls to poor men and boys (see also Klasen, 2004).

3. The Women's Working Group on Financing for Development is coordinated by the Southern-launched international feminist network Development Alternatives with Women for a New Era (DAWN). The Declaration emerging out of their second meeting in New York, held 24-26 April 2009, can be sourced on the website of the Association for Women's Rights in Development: http://www.awid.org/eng (accessed 15 July 2009).

4. See Kabeer (2003: 79ff) for an excellent discussion of different approaches to poverty analysis and measurement. Other useful sources include Chant (2007a: ch. 2), and on urban poverty specifically, Beall and Fox (2009: ch. 4).

5. Many 'shorthands' in the GAD field are discussed by Cornwall and Brock (2005) in the context of 'buzzwords'. See also Cornwall et al. (2007) on 'myths' and 'fables'.

6. I am grateful to Bart Casier for the reaffirmation, based on his extensive experience of development work with NGOs, that the reason why development projects are increasingly channelled through women is because they are deemed to be 'easier to work with' than men or youth.

7. Recent times have seen a massive increase in interest in the political and popular significance of development 'imagery', and the messages conveyed there in about people and poverty in the 'Global South'. As a prime, and up-to-the-minute example, the UNDP's Brasilia-based International Policy Centre for Inclusive Growth (IPC-IG) launched in June 2009 the 'Human Development Global Photography Campaign'. This campaign's website (http://www.ipc-undp.org/photo/), in its own words, encourages visitors and contributors to 'show development through a new lens, depicting examples of people winning the battle against poverty, social exclusion and marginalisation, rather than the usual desolation and despair we see in the media. The campaign aims at showing hope and success of development initiatives, empowering and inspiring people!'. According to a circular email sent on 20 July 2009, the website had received more than 35000 visitors and 'hundreds of beautiful pictures' since its launch seven weeks earlier.

8. This higher rate could conceivably be a function of more women attending healthchecks, especially when pregnant. I am grateful to Sarah Bradshaw for this observation.

9. In countries of the Global North, such as the UK, where class divisions have widened among men as well as among women, it is interesting that the gender pay gap in the lowest income decile is only 5 per cent compared with 20 per cent in the top decile. This reinforces the significance of intersectionality and class divisions among women, and I am especially grateful on this point to Diane Perrons.

10. In 2008 an additional target was added to MDG1 on eradicating extreme poverty and hunger, namely to 'achieve full and productive employment and decent work for all, including women and young people'. However, since the target (along with its component indicators) is not actually monitored in a gender- (or age-) specific way, and has no timeline (see http://www.mdgmonitor.org/goall.cfm, accessed 14 February 2010), this clearly begs the question of its potential efficacy in accomplishing purpose.

11. The UN celebrated its first year of Microcredit in 2005.

12. I am particularly grateful to Sarah Bradshaw and Cecilia Tacoli for their pointers on gender, poverty and climate change.

13. Credit is due to Gwendolyn Beetham for raising this issue.

\section{Select bibliography}

Afshar, Haleh (ed.) (2003) Development, Women and War: Feminist Perspectives, Oxford: Oxfam Professional.

Asian Development Bank (ADB) (2002) Sociolegal Status of Women in Indonesia, Malaysia, Philippines, and Thailand, Manila: ADB.

Barker, Gary, Marco Nascimento, Christine Ricardo and Marcio Segundo (2007) 'The individual and the political: PROMUNDO's evolving approaches in engaging young men in transforming masculinities', paper presented at international symposium 'Politicising Masculinities: Beyond the Personal', Dakar, Senegal, 15-18 October, available at: http://www.siyanda.org (accessed 30 January 2008).

Beall, Jo and Sean Fox (2009) Cities and Development, London: Routledge.

Blanc-Szanton, Cristina (1990) 'Gender and inter-generational resource allocation among Thai and Sino-Thai households', in Leela Dube and Rajni Palriwala (eds), Structures and Strategies: Women, Work and Family, New Delhi: Sage, pp. 79-102. 


\section{The international handbook of gender and poverty}

Bradshaw, Sarah (2002a) Gendered Poverties and Power Relations: Looking Inside Communities and Households, Managua: International Cooperation for Development/Embajada de Holanda/Puntos de Encuentro.

Bradshaw, Sarah (2002b) 'Exploring the gender dimensions of reconstruction processes post-Hurricane Mitch', Journal of International Development, 14, 871-9.

Bradshaw, Sarah (2008) 'From structural adjustment to social adjustment: a gendered analysis of conditional cash transfer programmes in Mexico and Nicaragua', Global Social Policy, 8 (2), 188-207.

Bradshaw, Sarah and Brian Linneker (2003) Challenging Women's Poverty: Perspectives on Gender and Poverty Reduction Strategies from Nicaragua and Honduras, London: Catholic Institute of International Relations.

Brickell, Katherine and Sylvia Chant (2010) 'The unbearable heaviness of being: reflections on female altruism from Cambodia, Philippines, The Gambia and Costa Rica', Progress in Development Studies, 10 (2).

Chant, Sylvia (1997) 'Women-headed households: poorest of the poor? Perspectives from Mexico, Costa Rica and the Philippines', IDS Bulletin, 28 (3), 26-48.

Chant, Sylvia (2007a) Gender, Generation and Poverty: Exploring the 'Feminisation of Poverty' in Africa, Asia and Latin America, Cheltenham, UK and Northampton, MA, USA: Edward Elgar.

Chant, Sylvia (2007b) Gender, Cities and the Millennium Development Goals in the Global South, Gender Institute New Series Working Paper, Issue 21, London: London School of Economics, available at: http:// www.lse.ac.uk/collections/genderInstitute/pdf/CHANT\%20GIWP.pdf (accessed 15 June 2009).

Chant, Sylvia (2008) 'The "feminisation of poverty" and the "feminisation" of anti-poverty programmes: room for revision?', Journal of Development Studies, 44 (2), 165-97.

Clark, Fiona and Caroline Moser (eds) (2001) Victims, Perpetrators or Actors? Gender, Armed Conflict and Political Violence, London: Zed.

Commission on Legal Empowerment of the Poor (CLEP) (2008) Making the Law Work for Everyone, New York: CLEP and United Nations Development Programme, available at: http://www.undp.org/legalempowerment/report/ (accessed 24 June 2009).

Cornwall, Andrea and Karen Brock (2005) Beyond Buzzwords. 'Poverty Reduction', 'Participation' and 'Empowerment' in Development Policy, Overarching Concerns, Programme Paper Number 10, Geneva: United Nations Research Institute for Social Development.

Cornwall, Andrea and Maxine Molyneux (eds) (2007) The Politics of Rights: Dilemmas for Feminist Praxis, Routledge: London.

Cornwall, Andrea, Sonia Correa and Susie Jolly (eds) (2008a) Development with a Body: Sexualities, Human Rights and Development, London: Zed.

Cornwall, Andrea, Justine Gideon and Kalpana Wilson (2008b) 'Introduction. Reclaiming feminism: gender and neoliberalism', IDS Bulletin, 39 (6), 1-9.

Cornwall, Andrea, Elizabeth Harrison and Ann Whitehead (2007) 'Introduction: feminisms in development: contradictions, contestations and challenges', in Andrea Cornwall, Elizabeth Harrison and Ann Whitehead (eds), Feminisms in Development: Contradictions, Contestations and Challenges, London: Zed, pp. 1-17.

Davids, Tine and Francien van Driel (2001) 'Globalisation and gender: beyond dichotomies', in Frans J. Schuurman (ed.), Globalisation and Development Studies: Challenges for the 21st Century, London: Sage, pp. $153-75$.

Davids, Tine and Francien van Driel (2005) 'Changing perspectives', in Tine Davids and Francien van Driel (eds), The Gender Question in Globalisation: Changing Perspectives and Practices, Aldershot: Ashgate, pp. $1-22$.

Deere, Carmen Diana and Cheryl Doss (2006) 'The gender asset gap: what do we know and why does it matter?', Feminist Economics, 12 (1), pp. 1-50.

Demetriades, Justine and Emily Esplen (2008) 'The gender dimensions of poverty and climate change adaptation', IDS Bulletin, 39 (4), 24-31.

Economic Commission for Latin America and the Caribbean (ECLAC) (2004) Roads Towards Gender Equity in Latin America and the Caribbean, Santiago de Chile: ECLAC.

Enarson, Elaine and P.G. Dhar Chakrabarti (eds) (2009) Women, Gender and Disaster: Global Issues and Initiatives, New Delhi: Sage.

Enarson, Elaine and Betty Morrow (eds) (1998) The Gendered Terrain of Disaster: Through Women's Eyes, Westport, CT: Praeger.

Fernández-Kelly, María Patricia and Saskia Sassen (1995) 'Recasting women in the global economy: internationalisation and changing definitions of gender', in Christine Bose and Edna Acosta-Belén (eds), Women in the Latin American Development Process, Philadelphia, PA: Temple University Press, pp. 95-124.

Folbre, Nancy (1994) Who Pays for the Kids? Gender and the Structures of Constraint, London: Routledge.

Folbre, Nancy (2006) 'Gender, empowerment, and the care economy', Journal of Human Development, 7 (2), 183-99.

Fonseca, Claudia (1991) 'Spouses, siblings and sex-linked bonding: a look at kinship organisation in a Brazilian slum', in Elizabeth Jelin (ed.), Family, Household and Gender Relations in Latin America, London: Kegan Paul International/Paris: United Nations Economic, Scientific and Cultural Organisation, pp. 133-60. 
Fukuda-Parr, Sakiko (1999) 'What does feminisation of poverty mean? It isn't just lack of income', Feminist Economics, 5 (2), 99-103.

Goetz, Anne-Marie and Rina Sen Gupta (1996) 'Who takes the credit? Gender, power and control over loan use in rural credit programmes in Bangladesh', World Development, 24 (1), 45-63.

González de la Rocha, Mercedes (2006a) Procesos Domésticos y Vulnerabilidad: Perspectivas Antropológicas de los Hogares con Oportunidades, Mexico City: Publicaciones de la Casa Chata.

González de la Rocha, Mercedes (2006b) 'Vanishing assets: cumulative disadvantages among the urban poor', in Patricia Fernández-Kelly and Jon Shefner (eds), Out of the Shadows: Political Action and the Informal Economy in Latin America, University Park, PA: Pennsylvania State University Press, pp. 97-124.

González de la Rocha, Mercedes (2007) 'The construction of the myth of survival', Development and Change, 38 (1), 45-66.

Grimshaw, Damian and Jill Rubery (2007) Undervaluing Women's Work, EOC Working Paper No. 53, Manchester: Equal Opportunities Commission.

Hart, Gillian (1995) 'Gender and household dynamics: recent theories and their implications', in Muhammad Ghulam Quibria (ed.), Critical Issues in Asian Development, Oxford: Oxford University Press, pp. 39-74.

Jackson, Cecile (1996) 'Rescuing gender from the poverty trap', World Development, 24 (3), 489-504.

Johnson, Robert (2005) 'Not a sufficient condition: the limited relevance of the gender MDG to women's progress', in Caroline Sweetman (ed.), Gender and the Millennium Development Goals, Oxford: Oxfam, pp. 56-66.

Johnsson-Latham, Gerd (2004) 'Understanding female and male poverty and deprivation', in Gerd JohnssonLatham (ed.), Power and Privileges: Gender Discrimination and Poverty, Stockholm: Regerinskanliet, pp. $16-45$.

Kabeer, Naila (1997) 'Editorial. Tactics and trade-offs: revisiting the links between gender and poverty', IDS Bulletin, 28 (3), 1-25.

Kabeer, Naila (2003) Gender Mainstreaming in Poverty Eradication and the Millennium Development Goals: A Handbook for Policy-makers and Other Stakeholders, London: Commonwealth Secretariat.

Klasen, Stephan (2004) Gender-related Indicators of Well-Being, Discussion Paper No. 102, Goettingen: Georg-August Universität, Ibero-Amerika Institüt für Wirtschaftsforschung, available at: http://www.iai. wiwi.uni-goettingen.de (accessed 20 January 2009).

Lampietti, Julian and Linda Stalker (2000) Consumption Expenditure and Female Poverty: A Review of the Evidence, Policy Research Report on Gender and Development, Working Paper Series No. 11, Washington, DC: World Bank, Development Research Group/Poverty Reduction and Economic Management Network.

Longwe, Sara Hlupekile (1995) 'A development agency as a patriarchal cooking pot: the evaporation of policies for women's advancement', in Mandy MacDonald (compiler), Women's Rights and Development, Oxford: Oxfam, pp. 18-29.

Marcoux, Alain (1998a) 'How much do we really know about the feminisation of poverty?', The Brown Journal of World Affairs, 5 (2), 187-94.

Marcoux, Alain (1998b) 'The feminisation of poverty: claims, facts and data needs', Population and Development Review, 24 (1), 131-9.

Mayoux, Linda (2006) Women's Empowerment through Sustainable Micro-finance: Rethinking 'Best Practice', Discussion Paper, Gender and Micro-finance, available at: http://www.genfinance.net (accessed 4 July 2008).

Mazurana, Dyan, Jane Parpart and Angela Raven-Roberts (eds) (2005) Gender, Conflict and Peacekeeping, Boulder, CO: Rowman and Littlefield.

Medeiros, Marcelo and Joana Costa (2006) Poverty Among Women in Latin America: Feminisation or Overrepresentation?, Working Paper No. 20, Brasilia: International Poverty Centre.

Medeiros, Marcelo and Joana Costa (2008) 'Is there a feminisation of poverty in Latin America?', World Development, 36 (1), 115-27.

Moghadam, Valentine (1997) The Feminisation of Poverty: Notes on a Concept and Trend, Women's Studies Occasional Paper No. 2, Normal, IL: Illinois State University.

Molyneux, Maxine (2006) 'Mothers at the service of the New Poverty Agenda: Progresa/Oportunidades, Mexico's conditional transfer programme', Journal of Social Policy and Administration, 40 (4), 425-49.

Molyneux, Maxine (2007) Change and Continuity in Social Protection in Latin America: Mothers at the Service of the State, Gender and Development Paper 1, Geneva: United Nations Research Institute for Social Development, available at: www.unrisd.org (accessed 31 July 2008).

Molyneux, Maxine and Shahra Razavi (eds) (2002) Gender Justice, Development and Rights, Oxford: Oxford University Press.

Moore, Henrietta (1994) Is There a Crisis in the Family?, Occasional Paper No. 3, World Summit for Social Development, Geneva: United Nations Research Institute for Social Development, available at: www. unrisd.org (accessed 20 June 2009).

Moser, Caroline (1998) 'The Asset Vulnerability Framework: reassessing urban Poverty Reduction Strategies', World Development, 26 (1), 1-19. 


\section{The international handbook of gender and poverty}

Moser, Caroline (ed.) (2007) Reducing Global Poverty: The Case for Asset Accumulation, Washington, DC: Brookings Press.

Parpart, Jane and Marysia Zalewski (2008) Rethinking the Man Question: Sex, Gender and Violence in International Relations, London: Zed.

Pearce, Diana (1978) 'The feminisation of poverty: women, work and welfare', The Urban and Social Change Review, 11, 23-36.

Perrons, Diane (2004) Globalisation and Social Change: People and Places in a Divided World, London: Routledge.

Piper, Nicola and Mina Roces (eds) (2002) Wife or Worker? Asian Women and Migration, Boulder, CO: Rowbotham and Littlefield.

Poverty-Environment Partnership (PEP) (2003) Poverty and Climate Change: Reducing the Vulnerability of the Poor through Adaptation, New York: PEP, available at: http://www.energyandenvironment.undp.org/undp/ index.cfm?module $=$ Library\&page $=$ Document $\&$ DocumentID $=5050$ (accessed 5 August 2009).

Quisumbing, Agnes and Bonnie McClafferty (2006) Using Gender Research in Development, Washington, DC: International Food Policy Research Institute.

Razavi, Shahra (ed.) (2009) The Gendered Impacts of Liberalisation: Towards 'Embedded Liberalism'?, Geneva: United Nations Research Institute for Social Development.

Razavi, Shahra and Shireen Hassim (eds) (2006) Gender and Social Policy in a Global Context: Uncovering the Global Structures of 'The Social', Geneva: United Nations Research Institute for Social Development.

Rodenberg, Birte (2004) Gender and Poverty Reduction: New Conceptual Approaches in International Development Cooperation, Reports and Working Papers 4/2004, Bonn: German Development Institute.

Roy, Ananya (2002) Against the Feminisation of Policy, Comparative Urban Studies Project Policy Brief, Washington, DC: Woodrow Wilson International Center for Scholars.

Ruxton, Sandy (2009) Man Made: Men, Masculinities and Equality in Public Policy, London: The Coalition for Men and Boys.

Sen, Gita (1999) 'Engendering poverty alleviation: challenges and opportunities', Development and Change, 30 (3), 685-92.

Sen, Gita (2008) 'Poverty as a gendered experience: the policy implications', Poverty in Focus, 13, 6-7, available at: http://www.undp-povertycentre.org/pub/IPCPovertyInFocus13.pdf (accessed 15 January 2009).

Sweetman, Caroline (2005) 'Editorial', in Caroline Sweetman (ed.), Gender and the Millennium Development Goals, Oxford: Oxfam, pp. 2-8.

Tanner, Thomas and Tom Mitchell (2008) 'Introduction: building the case for pro-poor adaptation', IDS Bulletin, 39 (4), 1-5.

Tronto, Joan (2002) 'The "nanny" question in feminism', Hypatia, 17 (2), 34-51.

United Nations (UN) Country Team/United Nations Fund for Women (UNIFEM) (2003) To Produce and to Care: How do Women and Men Fare in Securing Well-being and Human Freedoms?, Manila: UN Country Team/UNIFEM.

United Nations Department for Economic and Social Affairs (UN-DESA)/United Nations Division for the Advancement of Women (UNDAW) (2009) World Survey on the Role of Women in Development 2009: Women's Control over Economic Resources and Access to Financial Resources, Including Microfinance, New York: UN-DESA/UNDAW.

United Nations Development Programme (UNDP) (2000) Overcoming Human Poverty: UNDP Poverty Report 2000, New York: UNDP, available at: http://www.undp.org/povertyreport/Chapters/chap9.html (accessed 8 July 2009).

United Nations Millennium Project (UNMP)/Task Force on Education and Gender Equality (TFEGE) (2005) Taking Action: Achieving Gender Equality and Empowering Women, London: Earthscan, available at: http:// www.unmillenniumproject.org/documents/gender (accessed 16 June 2009).

Varley, Ann (1996) 'Women-headed households: some more equal than others?', World Development, 24 (3), 505-20.

Vera-Sanso, Penny (2006) 'Experiences in old age: a South Indian example of how functional age is socially structured', Oxford Development Studies, 34 (4), 457-72.

Vylder, Stefan de (2004) 'Gender in poverty reduction strategies', in Gerd Johnsson-Latham (ed.), Power and Privileges: Gender Discrimination and Poverty, Stockholm: Regerinskanliet, pp. 82-107.

Wennerholm, Carolina Johansson (2002) The 'Feminisation of Poverty': The Use of a Concept, Stockholm: Swedish International Development Cooperation Agency.

Whitehead, Ann and Matthew Lockwood (1999) 'Gendering poverty: a review of six World Bank African Poverty Assessments', Development and Change, 30 (3), 525-55.

Williams, Chris and Diana Lee-Smith (2000) 'Feminisation of poverty: re-thinking poverty reduction from a gender perspective', Habitat Debate, 6 (4), 1-5, available at: http://www.unhabitat.org/HD (accessed 24 July 2008). 